\title{
The genus Oedothorax Bertkau, 1883 in the Himalayas, with descriptions of four new species from Nepal (Aranei: Linyphiidae)
}

\author{
Род Oedothorax Bertkau, 1883 в Гималаях с описанием четырёх \\ новых видов из Непала (Aranei: Linyphiidae)
}

\begin{abstract}
Andrei V. Tanasevitch
A.В. Танасевич

A.N. Severtsov Institute of Ecology and Evolution, Russian Academy of Sciences, Leninsky prospekt 33, Moscow 119071, Russia. E-mail: tanasevitch@gmail.com

Институт проблем экологии и эволюции им. А.Н. Северцова РАН, Ленинский проспект 33, Москва 119071, Россия.
\end{abstract}

KEY WORDS: taxonomy, spiders, Erigoninae, mountain fauna, vertical distribution.

КЛЮЧЕВЫЕ СЛОВА: таксономия, пауки, Erigoninae, горная фауна, вертикальное распределение.

ABSTRACT. The Himalayas are the second largest centre of Oedothorax Bertkau, 1883 diversity, currently with at least 31 species involved. The largest centre is located in eastern Africa. Although this Afrotropical centre is formally composed not so much of Oedothorax species proper, but of those that are listed today in the genera Callitrichia Fage, 1936 and Toschia Caporiacco, 1949. However, most of them unquestionably belong to Oedothorax. As the Himalayan fauna of Oedothorax is restricted to low or middle elevations (270-2900 m a.s.1.), it seems to be Oriental in origin. The Himalayan, Oriental and Afrotropical species of Oedothorax (including Callitrichia and Toschia) are distinctly closer to each other than to the Palaearctic forms, but they are distinguished in some better expressed characters at the species level only. Four new species, Oedothorax cruciferoides sp.n., O. kathmandu sp.n., O. mangsima sp.n., and $O$. triceps sp.n., are described from Nepal. Data on the regional and altitudinal distributions of Oedothorax species in the Himalayan Mountains are presented.

How to cite this article: Tanasevitch A.V. 2020. The genus Oedothorax Bertkau, 1883 in the Himalayas, with descriptions of four new species from Nepal (Aranei: Linyphiidae) // Arthropoda Selecta. Vol.29. No.2. P.283-291. doi: 10.15298/arthsel. 29.2.15

РЕЗЮМЕ. Гималаи - второй по величине центр разнообразия рода Oedothorax Bertkau, 1883, насчитывающий не менее 31 вида. Крупнейший же центр расположен в Восточной Африке. Этот афротропический центр сформирован не столько собственно представителями рода Oedothorax, сколько видами, относимыми сегодня к родам Callitrichia Fage, 1936 и Toschia Caporiacco, 1949, подавляющее большинство которых, несомненно, относятся к роду Oedothorax. Гималайская фауна Oedothorax сосредоточена в низкогорьях и среднегорьях (2702900 м н.у.м.), что говорит об их вероятном ориен- тальном происхождении. Гималайские, ориентальные и афротропические виды Oedothorax (включая большинство видов Callitrichia и Toschia) существенно ближе друг к другу, чем к палеарктическим формам, но отличаются от последних лишь более экспрессивно выраженными признаками видового уровня. Четыре новых вида, Oedothorax cruciferoides sp.n., O. mangsima sp.n., O. kathmandu sp.n. и O. triceps sp.n. описаны из Непала. Приведены данные по региональному и вертикальному распространению представителей рода Oedothorax в Гималаях.

\section{Introduction}

At present, the genus Oedothorax Bertkau, in Förster et Bertkau, 1883 includes at least 76 species [World Spider Catalog, 2020] which are distributed in the Palaearctic, including the Himalayas (47 species), the Oriental Region (13), the Afrotropics (10), and the Nearctic (7). The fauna of the Himalayan Mountains is currently known to contain 26 Oedothorax species [Wunderlich, 1974; Thaler, 1987; Tanasevitch, 1998, 2015, 2016], 19 of them being recorded from Nepal. Representatives of Oedothorax occur in the Himalayas only at low to middle altitudes, none having been found above $3000 \mathrm{~m}$ a.s.1. Descriptions of four new species, as well as notes on the distributions of the Oedothorax species in the Himalayas are the subject of the present paper.

\section{Material and methods}

This paper is based on the spider material collected during expeditions arranged by Prof. Jochen Martens in Nepal, and kept in the Senckenberg Museum, Frankfurt am Main, Germany (SMF), as well as on the samples found in collections of the Muséum d'histoire naturelle de Genève, Switzerland (MNHG). The sample number is given in square brackets. All specimens are preserved in $70 \%$ ethanol and 


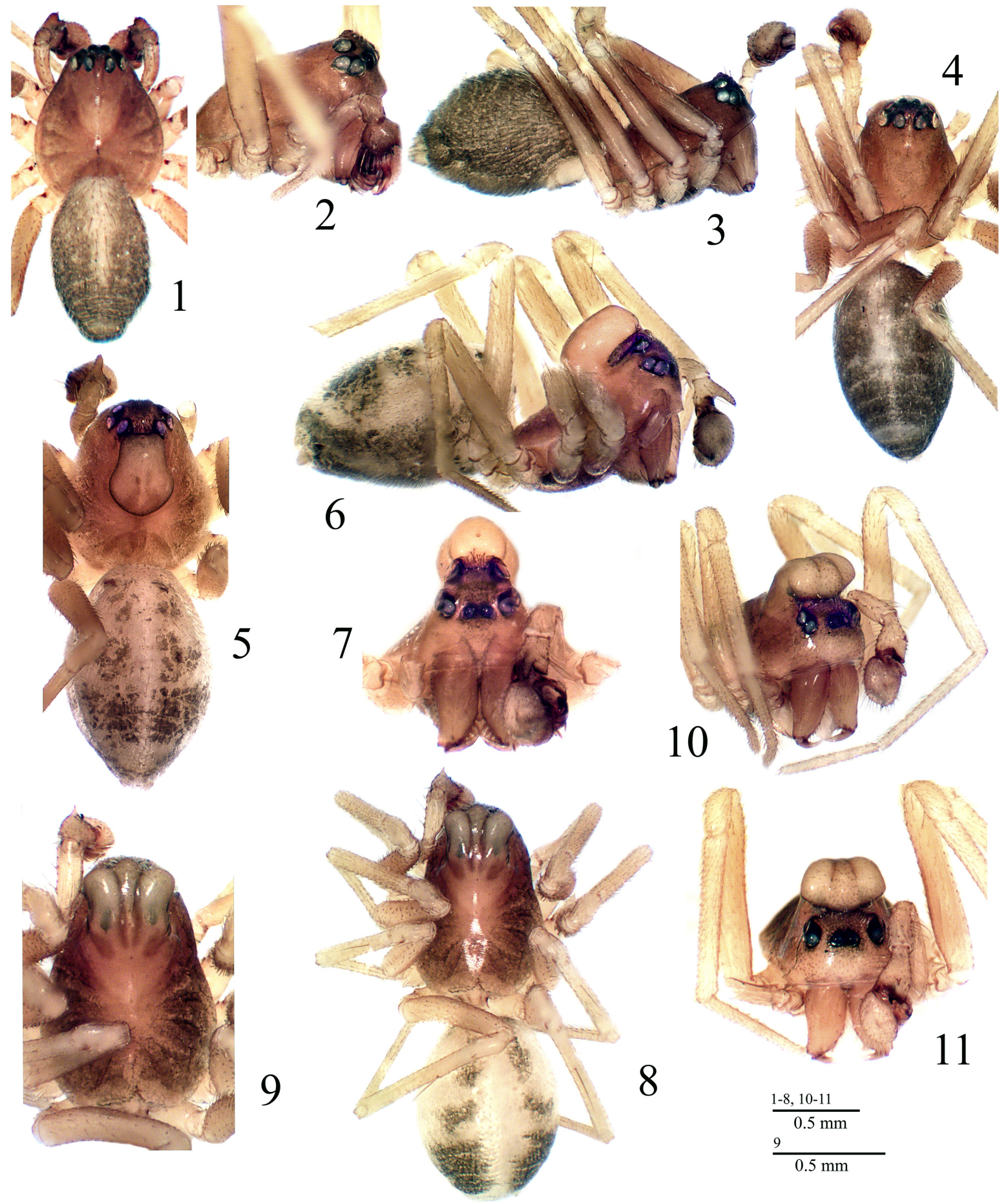

Figs 1-11. Pictures of Oedothorax cruciferoides sp.n. (1-3), O' holotype (1-2), O' paratype (3); O. kathmandu sp.n., O' holotype (4); $O$. mangsima sp.n., $O^{7}$ holotype (5-7), and $O$. triceps sp.n., $O^{7}$ holotype (8-11). 1, 4-5, 8 - habitus, dorsal view, 3, 6 - habitus, lateral view, 2, 7, 9-11 - prosoma, 2, 10 - antero-lateral view, 9 - dorsal view, 7, 11 - frontal view.

Рис. 1-11. Фотографии Oedothorax cruciferoides sp.n. (1-3), О7 голотип (1-2), О7 паратип (3); O. kathmandu sp.n., О7 голотип (4); O. mangsima sp.n., О' голотип (5-7); O. triceps sp.n., О7 голотип (8-11). 1, 4-5, 8- внешний вид сверху; 3, 6 - внешний вид сбоку; 2, 7, 9-11 - головогрудь, 2, 10 - вид спереди и сбоку, 9 - вид сверху, 7, 11 - вид спереди.

have been studied using a MBS-9 stereo microscope. A Levenhuk C-800 digital camera was applied for taking some pictures. The sequence of leg segment measurements is as follows: femur + patella + tibia + metatarsus + tarsus. All measurements are given in millimeters. The chaetotaxy is given in a formula, e.g., 2.2.1.1, which refers to the number of dorsal spines on tibiae I-IV. Scale bars in the figures correspond to $0.1 \mathrm{~mm}$ unless indicated otherwise. Figure 

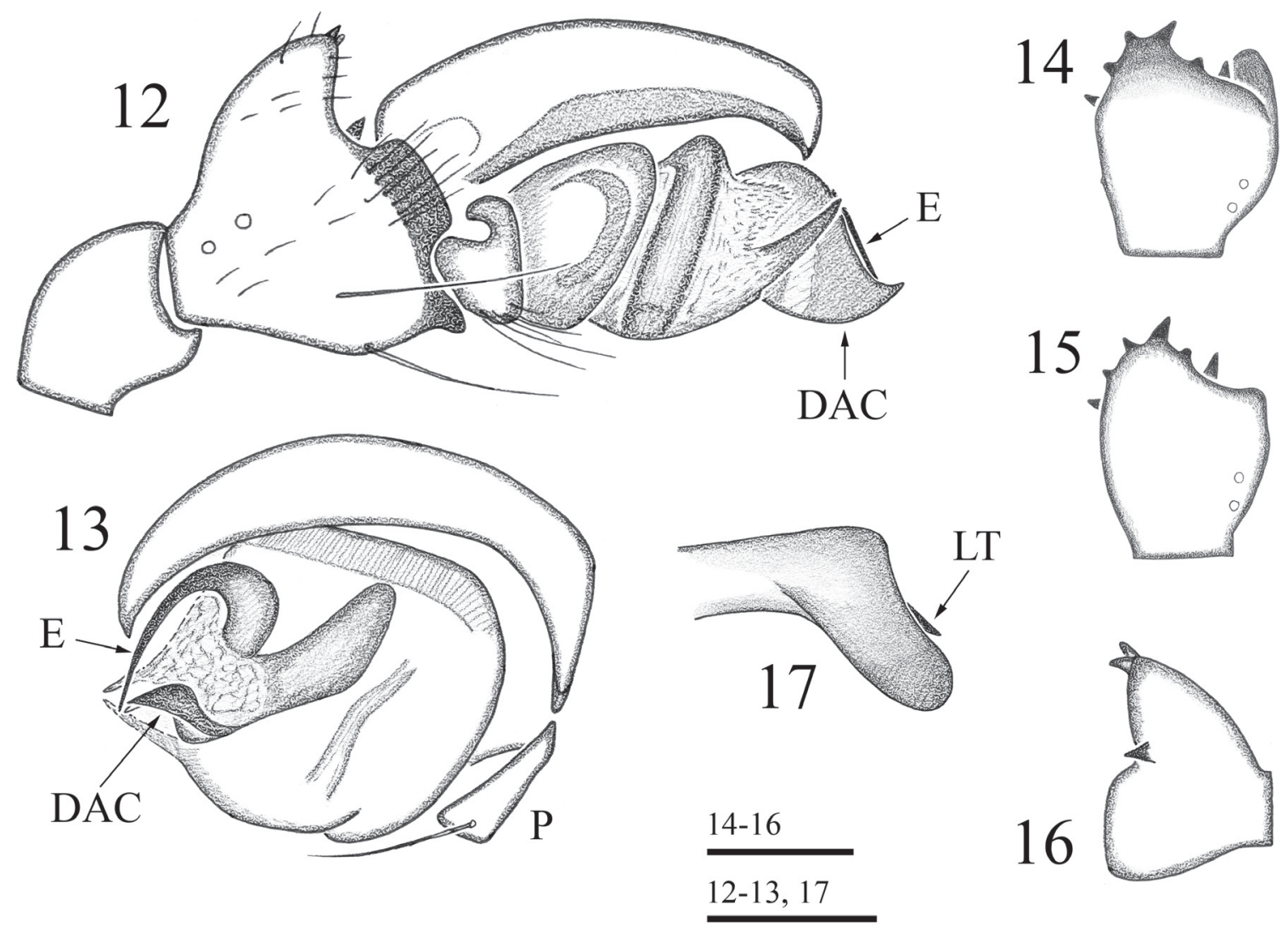

Figs 12-17. Details of male palpal structure of Oedothorax cruciferoides sp.n., o paratype: 12-13 - right palp, retro- and ventroprolateral views, respectively; $14-15$ - palpal tibia, dorsal view, different aspects, 16 - same, prolateral view; 17 - distal suprategular apophysis.

Рис. 12-17. Детали строения пальпы Oedothorax cruciferoides sp.n., О паратип: 12-13 - правая пальпа, ретро- и вентропролатерально, соответственно; 14-15 — голень пальпы, дорсально, различные аспекты, 16 - тоже, пролатерально и снизу; 17 дистальный супратегулярный отросток.

numbers are shown above the scale bars, the representing length below them. The modern nomenclature of the palpal sclerites and its parts follows of Tanasevitch [2015].

The following abbreviations are used in the text and figures: a.s.l. — above sea level, DAC — distal apophysis of convector, DSA - distal suprategular apophysis after Hormiga [2000], E - embolus, LEC - lateral extension of convector, LT - lateral tooth of DSA, MBC - main body of convector, $\mathrm{Mt}$ - metatarsus, $\mathrm{P}$ - paracymbium, $\mathrm{Pr}-$ protegulum, $\mathrm{R}$ - radix, $\mathrm{Ti}-$ tibia, $\mathrm{TmI}-$ position of trichobothrium on metatarsus I.

\section{Descriptions}

Order Aranei Clerck, 1758

Family Linyphiidae Blackwall, 1859

Genus Oedothorax Bertkau,

in Förster et Bertkau, 1883

Type species Oedothorax gibbosus (Blackwall, 1841).

Oedothorax cruciferoides sp.n.

Figs 1-3, 12-17.

HOLOTYPE $\sigma^{7}$ (SMF), NEPAL, Ilam District, $5 \mathrm{~km} \mathrm{~N}$ of
Sanishare, feet of Siwalik Mts, 270-300 m a.s.1., mixed Shorea forest, 3-5.IV.1988, leg. J. Martens \& W. Schawaller [\#308].

PARATYPE. $1 \mathrm{O}^{7}$ (SMF), Panchthar District, Paniporua, 2300 m a.s.1., mixed broadleaved forest, 16-20.IV.1988, leg. J. Martens \& W. Schawaller [\#328].

NAME. The specific epithet refers to the holotype resembling the Oriental species Nasoona crucifera (Thorell, 1895).

DIAGNOSIS. The new species is clearly distinguished by a combination of the following characters: poorly modified carapace bearing a particular, small, conical elevation; palpal tibia positioned along the distal edge with four dentiform tubercles; a well-developed radix and a relatively long embolus. The shape of the distal apophysis of the convector is especially characteristic and looks like a paraconvector in Nasoona crucifera.

DESCRIPTION. Male (paratype). Total length 1.85. Carapace slightly modified, 0.85 long, 0.68 wide, reddish-brown. Its cephalic part with a small, conical elevation situated between posterior median eyes, and bearing a group of short spines, as shown in Figs 2-3. Eyes slightly enlarged. Chelicerae unmodified, 0.35 long, a mastidion absent. Legs brown to pale brown. Leg I, 2.99 long $(0.83+0.23+0.75+0.68+$ $0.50)$, IV, 3.16 long $(0.85+0.20+0.83+0.78+0.50)$. Chaetotaxy: 2.2 .1 .1 , spines $1.5-2 \mathrm{x}$ as long as diameter of corresponding leg segment. Each metatarsus with a tricho- 


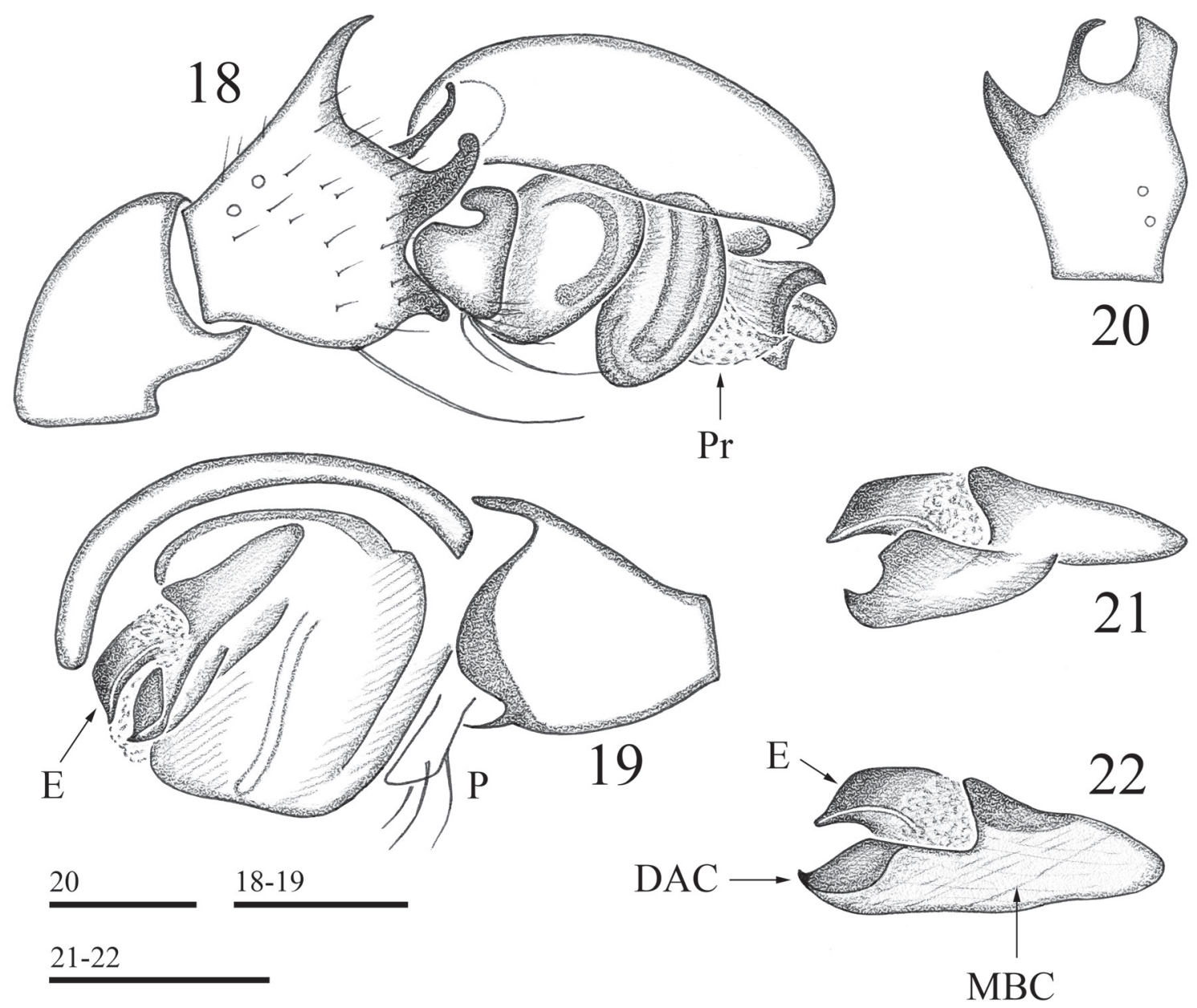

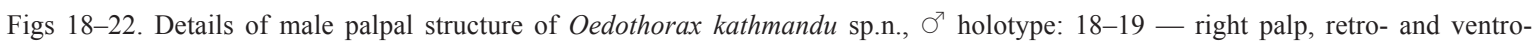
prolateral views, respectively; 20 - palpal tibia, dorsal view; 21-22 - different aspects.

Рис. 18-22. Детали строения пальпы Oedothorax kathmandu sp.n., о голотип: 18-19 - правая пальпа, ретро- и вентропролатерально, соответственно; 20 - голень пальпы, вид сверху; 21-22 - эмболюсный отдел, различные аспекты.

bothrium. TmI 0.52. Palp (Figs 12-17). Patella shorter than tibia. Tibia elongated dorsally, with four small dentiform tubercles at its distal, conical edge, and a keel-shaped outgrowth retrolaterally with a strong tooth at its upper side. Retrolaterally tibia bearing a pointed tooth. Paracymbium relatively small, its median part bearing several long, but stout spines. Tegulum distally with two membraneous, protegulum-like processes: upper one rounded, second one lower, longer, slightly sclerotized distally, dagger-shaped. Distal suprategular apophysis short, rounded apically, with a small, sharp, lateral tooth near middle. Radix small, slightly curved, embolus falcate. Main body of convector narrow, elongated, somewhat curved. Distal apophysis of convector flat, broadened. Abdomen 1.18 long, 0.70 wide, dorsal pattern as in Fig. 1.

Female unknown.

TAXONOMIC REMARKS. The shape of the distal part of the embolic division in $O$. cruciferoides sp.n. is similar to that of Nasoona crucifera. The main difference lies in where the distal section of the embolic division is formed. In the new species, this part is the distal apophysis of the convector (DAC in Fig. 12), vs. a paraconvector, an additional palpal sclerite in $N$. crucifera which is missing in Oedothorax species (see Tanasevitch $[2014,2018]$ ).

DISTRIBUTION. Known from Panchthar and Ilam districts, Nepal.

\section{Oedothorax kathmandu sp.n.}

Figs 4, 18-22.

HOLOTYPE $0^{7}$ (SMF), NEPAL, Kathmandu, Balaju Park, mixed forest, $1400 \mathrm{~m}$ a.s.1., 17.III.1980, leg. J. Martens \& A. Ausobsky [\#104].

NAME. The specific epithet is a noun in apposition referring to the "terra typica", the Kathmandu Valley in the Himalayas of Nepal.

DIAGNOSIS. The new species is diagnosed by a combination of the following characters: presence of three characteristic distal apophyses on the the palpal tibia; a wide and very short embolus with a totally reduced radix; and a special shape of the convector with its distal apophysis being very small.

DESCRIPTION. Male (holotype). Total length 1.95. Carapace unmodified, as shown in Fig. 4, 0.93 long, 0.70 


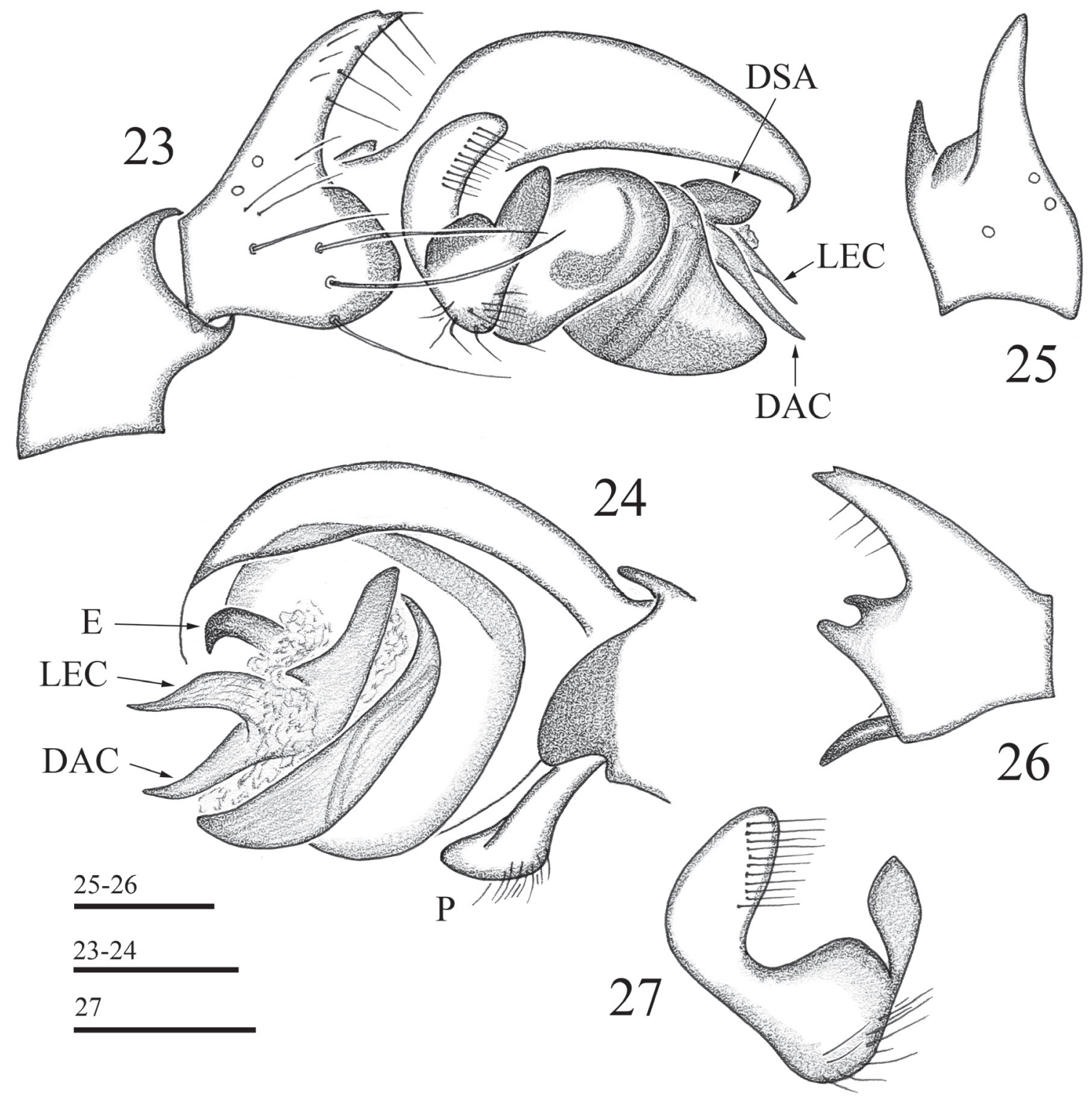

Figs 23-27. Details of male palpal structure of Oedothorax mangsima sp.n., $\sigma^{7}$ holotype: $23-24$ - right palp, retro- and ventroprolateral views, respectively; $25-26$ - palpal tibia, dorsal and prolateral views, respectively; 27 - paracymbium.

Рис. 23-27. Детали строения пальпы Oedothorax mangsima sp.n., О голотип: 23-24 - правая пальпа, ретро- и вентропролатерально, соответственно; 25-26 — голень пальпы, вид сверху и пролатерально; 27 - парацимбиум.

wide, brown. Eyes slightly enlarged. Chelicerae unmodified, 0.35 long, a mastidion absent. Legs pale brown to yellow. Leg I, 3.22 long $(0.88+0.28+0.75+0.78+0.53)$, IV, 3.44 long $(0.90+0.28+0.88+0.90+0.48)$. Chaetotaxy: 2.2.1.1, spines $1-1.5 \mathrm{x}$ as long as diameter of corresponding leg segment. Each metatarsus with a trichobothrium. TmI 0.44. Palp (Figs 18-22). Patella shorter than tibia. Tibia with three apophyses differing in shape and size. Distal part of paracymbium broadened and bearing relatively long, curved spines. Distal suprategular apophysis very short, rounded distally. Embolus small and thick, claw-shaped, radix reduced. Convector with a distal apophysis being a small, curved denticle, lateral extention short, arising near middle of main body of convector. Abdomen 1.13 long, 0.63 wide, dorsal pattern as in Fig. 4.
REMARKS. So far, it seems too hard to bring $O$. kathmandu sp.n. close enough to any other of the known congeners. The unmodified carapace, as well as the special shapes of the palpal structures make this species well distinguished and isolated.

DISTRIBUTION. Known only from the type locality, Kathmandu Valley in the Himalayas of Nepal.

\section{Oedothorax mangsima sp.n.}

Figs 5-7, 23-27.

HOLOTYPE Ơ (MHNG), NEPAL, Kosi (= Koshi) Province, Sankhuwasawa District, Mangsima, $2200 \mathrm{~m}$ a.s.1, forest south of Mangsima, ravine, sifting dead leaves, mosses and rotten wood, 11.IV.1984, leg. I. Löbl \& A. Smetana [\#13]. 


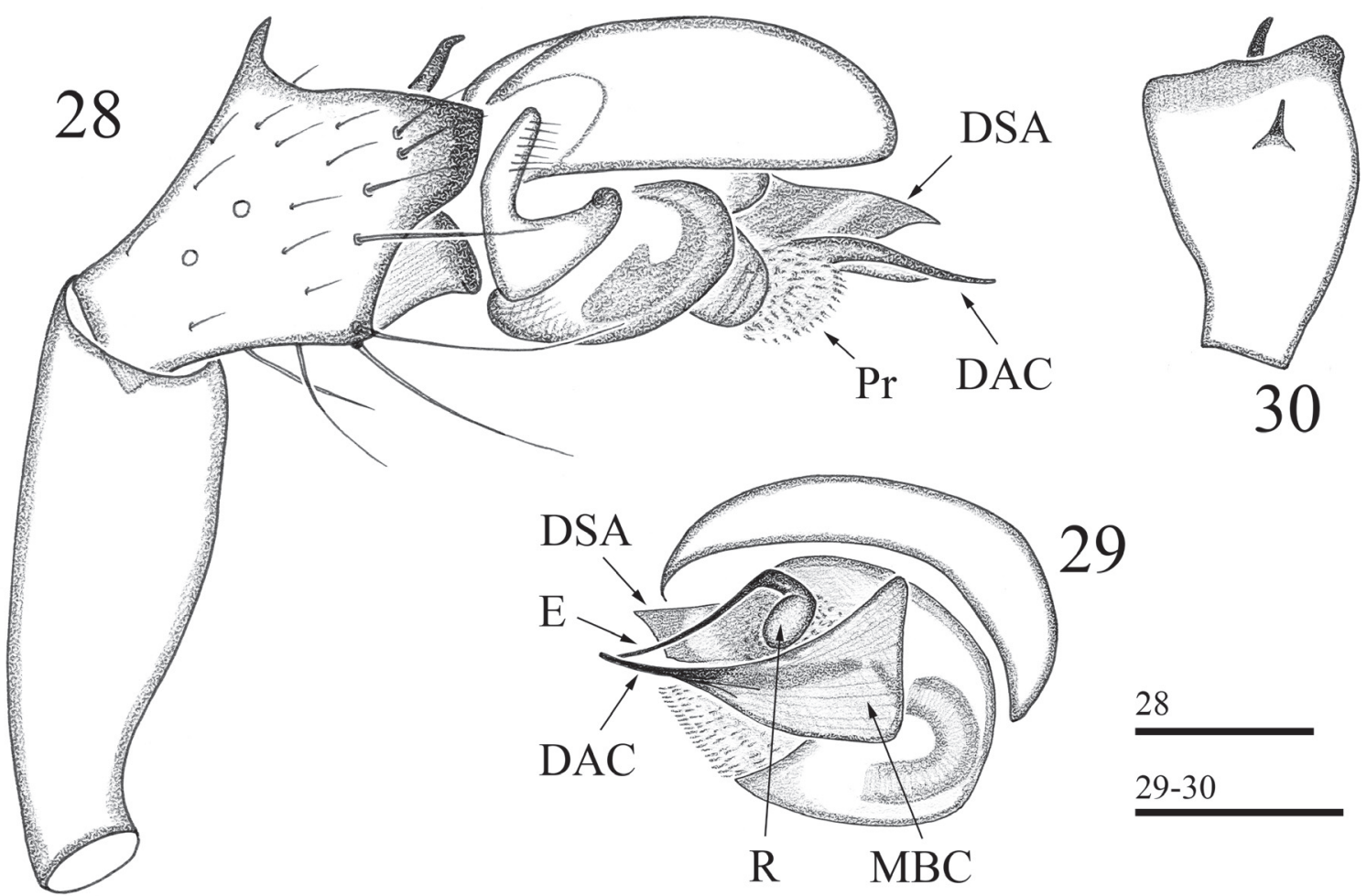

Figs 28-30. Details of male palpal structure of Oedothorax triceps sp.n., ${ }^{7}$ holotype: $28-29$ - right palp, retro- and ventro-prolateral views, respectively; 30 - palpal tibia, dorsal view.

Рис. 28-30. Детали строения пальпы Oedothorax triceps sp.n., о голотип: 28-29 - правая пальпа, ретро- и вентро-пролатерально, соответственно; 30 - голень пальпы, вид сверху.

NAME. The specific name is a noun in apposition taken from the name of the type locality, Mangsima, Kosi Province, Nepal.

DIAGNOSIS. The new species is diagnosed by the characteristic shape of the carapace, the structure of the palpal tibia, the special shape of the paracymbium, as well as by the totally reduced radix, and both distal apophysis and lateral extention of the convector being long, slender and slightly curved

DESCRIPTION. Male (holotype). Total length 2.15. Carapace strongly modified, 1.00 long, 0.83 wide, pale brown. Carapace behind posterior median eyes with a large, rounded elevation, separated from cephalic part by long and narrow sulci, as shown in Figs 5-7. Chelicerae unmodified, 0.40 long, a mastidion absent. Legs pale brown to yellow. Leg I, 3.89 long $(1.08+0.30+0.88+1.00+0.63)$, IV , 4.11 long $(1.10+0.30+1.03+1.08+0.60)$. Chaetotaxy: dorsal tibial spines lost, but pattern probably 2.2.1.1. Each metatarsus with a trichobothrium. TmI 0.52. Palp (Figs 23-27). Patella about as long as tibia. Tibia extended dorsally into a long, claw-shaped outgrowth, a prolateral outgrowth bifid. Paracymbium relatively large, U-shaped, its proximal part bearing numerous thin spines, middle part broadened, with a group of stout, curved spines. Distal suprategular apophysis very short, well-sclerotized, truncate apically. Embolus small, dark, claw-shaped, radix totally reduced. Main body of convector elongated, relatively narrow, its distal apophysis and lateral extention slender and slightly curved. Abdomen 1.25 long, 0.83 wide, dorsal pattern as in Fig. 5.

Female unknown.
TAXONOMIC REMARKS. By its large postocular elevation, $O$. mangsima sp.n. resembles some Himalayan congeners, i.e., O. globiceps Thaler, 1987, O. lineatus Wunderlich, 1974, O. sexoculatus Wunderlich, 1974, O. sexoculorum Tanasevitch, 1998, etc., but in the new species the postocular elevation is separated from the ocular area by long and narrow sulci. The structure of the embolic division somewhat resembles that of $O$. stylus Tanasevitch, 2015, known from Kerala, India [Tanasevitch, 2015]. The new species is clearly distinguishable from the latter congener by the strongly modified carapace and the peculiar shape of the palpal tibia.

DESCRIPTION. Known only from the type locality in Kosi Province, Nepal.

\section{Oedothorax triceps sp.n.}

Figs 8-11, 28-30.

HOLOTYPE $0^{7}$ (MHNG), NEPAL, Bagmati Province, Dobate Ridge northeast of Barahbise, $2800 \mathrm{~m}$ a.s.l., sifting rotten wood, dead leaves and moss in oak grove with Rhododendron, 2.V.1981, leg. I. Löbl \& A. Smetana [\#55d].

NAME. The specific name is derived from the shape of the carapace as observed in the holotype.

DIAGNOSIS. The species is diagnosed by the presence of a trilobate postocular elevation on the male carapace, a long palpal patella, the shape and arrangement of the palpal tibial outgrowths, as well as by the structure of the embolic division, namely, a pyramidal convector with its distal apophysis being long and slender. 
DESCRIPTION. Male (holotype). Total length 2.00. Carapace strongly modified, 1.00 long, 0.68 wide, pale brown. Its cephalic part with a large, rounded elevation, somewhat divided into three parts and overhanging the ocular area, as shown in Figs 10-11. Posterior median eyes incorporated into base of elevation. Chelicerae unmodified, 0.38 long, a mastidion absent. Legs pale brown to yellow. Leg I, 2.97 long $(0.88+0.25+0.68+0.68+0.48)$, IV, 3.03 long $(0.85+$ $0.25+0.75+0.78+0.40)$. Chaetotaxy: dorsal tibial spines mostly lost, should be 2.2.1.1. Each metatarsus with a trichobothrium. TmI 0.82. Palp (Figs 28-30). Patella almost twice as long as tibia. Tibia with two outgrowths: dorsal one a sharp and pale tooth, apical one black and slightly curved. Paracymbium relatively small, L-shaped, its proximal part bearing numerous thin spines. Tegulum with a large, broad protegulum. Distal suprategular apophysis wide and flat, obliquely trimmed distally. Radix small, slightly elongated, embolus slender and relatively long. Convector flat, nearly pyramid-shaped, its distal apophysis long and slender. Abdomen. 1.13 long, 0.75 wide, dorsal pattern as in Fig. 8 .

Female unknown.

TAXONOMIC REMARKS. A relatively long embolus with a small, but well-defined radix are not rare among Oedothorax, occurring e.g., in O. agrestis (Blackwall, 1853), O. paracymbialis Tanasevitch, $2015, O$. paralegrandi $\mathrm{Ta}-$ nasevitch, 2016, etc. The shapes of both embolus and convector slightly resemble those in $O$. paralegrandi, known from Himalayas [Tanasevitch, 2016]. Oedothorax triceps sp.n. is distinctly different from other congeners by the specific characters given above in Diagnosis.

DISTRIBUTION. Known only from the type locality in Bagmati Province, Nepal.

\section{Discussion}

The Himalayas are presently the second largest centre of Oedothorax diversity, comprising at least 31 species, 24 of which are known from Nepal (see Table 1). This Himalayan centre is composed of endemic species only, being inferior in species richness only to the largest centre which located in eastern Africa, namely, Kenya, Tanzania and Uganda. The Afrotropical centre presently supports no less than 40 species, being formally composed not so much of Oedothorax species proper, as mostly of those that are listed today in the genera Callitrichia Fage, 1936 and Toschia Caporiacco, 1949 (see Caporiacco [1949], Holm [1962], Jocqué \& Scharff [1986], Wunderlich [1978], Scharff $[1990 \mathrm{a}, \mathrm{b}]$, etc.). The taxonomic status of the genera Oedothorax, Callitrichia and Toschia has been discussed several times [Holm, 1962, Jocqué, 1983, Scharff, 1990a, Wunderlich, 1978], but today all these genera are still considered independent. In my opinion, however, most species of Callitrichia and Toschia are undoubtedly belong to Oedothorax, but no formal transfers are advanced here. The opinion is primarily based on the same conformation of the secondary genital organs, as well as the same chaeto- and trichobothriotaxy as observed in representatives of these three (or more) genera. It seems noteworthy that the Himalayan, Oriental and Afrotropical species of Oedothorax, including Callitrichia and Toschia, are clearly more sim- ilar to each other than to the Palaearctic forms, but they are distinguished in better expressed characters at the species level only. These basic shared characters are as follows: the modified/unmodified carapace; the number, shape and location of outgrowths on the palpal tibia; the presence, shape and size of both distal apophysis and lateral extension of the convector (see Wiehle [1956], Wunderlich [1974], Roberts [1987], Tanasevitch [1998, 2014, 2015, 2016, 2017a, b, c, 2020], etc.). However, with a few marginal exceptions only, variations in these palpal structural details fail to surpass the species limits, while the lack of real morphological synapomorphies does not make it possible to clearly distinguish any supraspecific taxa.

Table 1 shows the distribution of Oedothorax species in the Himalayas. The largest number of species (24) can be seen in Nepal, while the other regions of this exceptionally vast and varied mountain system contain only between one and four species. However, such a strong disproportion is clearly the result of Nepal, however incompletely prospected yet, being far better explored compared to virtually any other comparably large territory of the Himalayas. The table also shows that representatives of Oedothorax occur only at low to middle elevations, never found above $3000 \mathrm{~m}$ a.s.l. to suggest a Palaearctic stem. Such a pattern of distribution may be evidence of the Himalayan fauna of Oedothorax being entirely of Oriental origins. This is also confirmed by many Himalayan Oedothorax strongly resembling certain species known from the Oriental Region (see Tanasevitch [2015, 2017a, b, c, 2018, 2020]).

Acknowledgements. I am most grateful to Peter Schwendinger (MHNG), as well as Peter Jäger and Julia Altmann (both SMF), who supplied me with the samples under their care. I also thank Sergei I. Golovatch (Moscow) for editing an advanced draft of the manuscript.

This study was supported in part by the Presidium of the Russian Academy of Sciences, Program \#41 "Biodiversity of natural systems and biological resources of Russia".

\section{References}

Caporiacco L. di. 1949. Aracnidi della colonia del Kenya raccolti da Toschi e Meneghetti negli anni 1944-1946 // Commentationes Pontificia Academia Scientiarum. Vol.13. P.309-492.

Holm Å. 1962. The spider fauna of the East African mountains. Part I: Fam. Erigonidae // Zoologiska Bidrag från Uppsala. Vol.35. P.19-204.

Hormiga G. 2000. Higher level phylogenetics of erigonine spiders (Araneae, Linyphiidae, Erigoninae) // Smithsonian Contributions to Zoology. Vol.609. P.1-160.

Jocqué R. 1983. Sur la synonymie de Callitrichia Fage et Atypena Simon avec la redescription de quelques espèces paléotropicales (Araneae, Linyphiidae) // Bulletin du Muséum national d'Histoire naturelle de Paris. T.4. Fasc.5(A). P.235-245.

Jocqué R., Scharff N. 1986. Spiders (Araneae) of the family Linyphiidae from the Tanzanian mountain areas Usambara, Uluguru and Rungwe // Annalen Zoologische Wetenschappen. Bd.248. S. 1-61.

Roberts M.J. 1987. The spiders of Great Britain and Ireland. Volume 2: Linyphiidae and check list. Colchester. England: Harley Books. 204 pp. 
Table 1. Distribution of Oedothorax species in the Himalayas. Таблица 1. Распространение пауков рода Oedothorax в Гималаях.

\begin{tabular}{|c|c|c|c|c|c|c|c|}
\hline \multirow{3}{*}{ Species of Oedothorax } & \multicolumn{7}{|c|}{ The Himalayan Mountains } \\
\hline & \multirow[t]{2}{*}{ Pakistan } & \multicolumn{3}{|c|}{ India } & \multirow[t]{2}{*}{ Nepal } & \multicolumn{2}{|c|}{$\begin{array}{l}\text { Altitudes } \\
\text { (m a.s.l.) }\end{array}$} \\
\hline & & J.\&K. & H.P. & W.B. & & Min & $\operatorname{Max}$ \\
\hline O. angelus Tanasevitch, 1998 & & & & & + & 2300 & 2700 \\
\hline O. annulatus Wunderlich, 1974 & & & & & + & 1800 & 2000 \\
\hline O. assuetus Tanasevitch, 1998 & & & & & + & 1700 & 1700 \\
\hline O. caporiaccoi Roewer, 1942 & + & & & & & 2000 & 2000 \\
\hline O. cf. annulatus Wunderlich, 1974 & & & & & + & 1800 & 2100 \\
\hline O. clypeellum Tanasevitch, 1998 & & & & & + & 2600 & 2600 \\
\hline O. cornutus Tanasevitch, 2015 & & & & + & & 2500 & 2600 \\
\hline O. coronatus Tanasevitch, 1998 & & & & & + & 1900 & 2300 \\
\hline O. cruciferoides sp.n. & & & & & + & 270 & 2300 \\
\hline O. dismodicoides Wunderlich, 1974 & & & & & + & 2460 & 2750 \\
\hline O. elongatus Wunderlich, 1974 & & & & & + & 2000 & 2100 \\
\hline O. falcifer Tanasevitch, 1998 & & & & & + & 2000 & 2000 \\
\hline O. falciferoides Tanasevitch, 2015 & & & & + & & 1200 & 1200 \\
\hline O. globiceps Thaler, 1987 & & + & & & & 2400 & 2400 \\
\hline O. hirsutus Wunderlich, 1974 & & & & & + & 1800 & 2000 \\
\hline O. kathmandu sp.n. & & & & & + & 1400 & 1400 \\
\hline O. lineatus Wunderlich, 1974 & & & & & + & 2700 & 2800 \\
\hline O. lopchu Tanasevitch, 2015 & & & & + & & 2000 & 2000 \\
\hline O. lucidus Wunderlich, 1974 & & & & & + & 1800 & 2900 \\
\hline O. mangsima sp.n. & & & & & + & 2200 & 2200 \\
\hline O. malearmatus Tanasevitch, 1998 & & & & & + & 2300 & 2300 \\
\hline O. modestus Tanasevitch, 1998 & & & & & + & 2300 & 2300 \\
\hline O. paralegrandi Tanasevitch, 2016 & & & + & & & 1950 & 1950 \\
\hline O. savigniformis Tanasevitch, 1998 & & & & & + & 2300 & 2600 \\
\hline O. sexoculatus Wunderlich, 1974 & & & & & + & 2330 & 2500 \\
\hline O. sexoculorum Tanasevitch, 1998 & & & & & + & 2450 & 2850 \\
\hline O. simplicithorax Tanasevitch, 1998 & & & & & + & 1750 & 1750 \\
\hline O. tholusus Tanasevitch, 1998 & & & & & + & 2100 & 2100 \\
\hline O. triceps sp.n. & & & & & + & 2800 & 2800 \\
\hline O. unicolor Wunderlich, 1974 & & & & & + & 1400 & 1700 \\
\hline O. villosus Tanasevitch, 2015 & & & & + & & 1800 & 1800 \\
\hline Total species (31) & 1 & 1 & 1 & 4 & 24 & & \\
\hline
\end{tabular}

Legend: J.\&K. — Jammu and Kashmir, H.P. — Himachal Pradesh, W.B. — West Bengal.

Scharff N. 1990a. Spiders of the family Linyphiidae from the Uzungwa mountains, Tanzania (Araneae) // Entomologica Scandinavica, Supplement 36. P.1-95.

Scharff N. 1990b. A catalogue of African Linyphiidae (Araneae) // Steenstrupia. Vol.16. P.117-152.

Tanasevitch A.V. 1998. New Oedothorax Bertkau, 1883 from Nepal (Arachnida, Araneae, Linyphiidae) // Bonner Zoologische Beiträge. Bd.47. N.3-4. P.429-441.

Tanasevitch A.V. 2014. New species and records of linyphiid spiders from Laos (Araneae, Linyphiidae) // Zootaxa. Vol.3841. No.1. P.67-89.
Tanasevitch A.V. 2015. Notes on the spider genus Oedothorax Bertkau, 1883 with description of eleven new species from India (Linyphiidae: Erigoninae) // Revue suisse de Zoologie. T.122. Fasc.2. P.381-398.

Tanasevitch A.V. 2016. A case of disjunct montane linyphiid species (Araneae) in the Palaeotropics, with notes on synonymy and the description of a new species // Revue suisse de Zoologie. T.123. Fasc.2. P.235-240.

Tanasevitch A.V. 2017a. New genera and new species of the family Linyphiidae from Borneo, Sumatra and Java (Arachnida: Araneae) // Revue suisse de Zoologie. T.124. Fasc.1. P.141-155. 
Tanasevitch A.V. 2017b. Another new Oedothorax Bertkau, 1883 from India (Arachnida, Araneae) // Revue suisse de Zoologie. T.124. Fasc.2. P.331-333.

Tanasevitch A.V. 2017c. New species and new records of linyphiid spiders from the Indo-Malayan Region (Araneae, Linyphiidae) // Zootaxa. Vol.4227. N3. P.325-346.

Tanasevitch A.V. 2018. A survey of the genus Nasoona Locket, 1982 with the description of six new species (Araneae, Linyphiidae) // Revue suisse de Zoologie. T.125. Fasc.1. P.87-100.

Tanasevitch A.V. 2020. Two new Oedothorax Bertkau, 1883 from eastern India (Aranei: Linyphiidae) // Arthropoda Selecta. Vol.29. No.1. P.127-131.

Thaler K. 1987. Über einige Linyphiidae aus Kashmir (Arachnida: Araneae) // Courier Forschungsinstitut Senckenberg. Bd.93. S.33-42.
Wiehle H. 1956. Spinnentiere oder Arachnoidea (Araneae). 28. Familie Linyphiidae - Baldachinspinnen // Die Tierwelt Deutschlands. Bd.44. S.1-337.

World Spider Catalog 2020. World Spider Catalog, version 21.0. Natural History Museum Bern. Online at http://wsc.nmbe.ch (accessed in April, 2020).

Wunderlich J. 1974. Linyphiidae aus Nepal, II. Die Gattung Oedothorax Bertkau 1883 (Arachnida: Araneae) // Senckenbergiana Biologica. Bd.55. S.169-188.

Wunderlich J. 1978. Zur Kenntnis der Gattungen Oedothorax Bertkau 1883, Callitrichia Fage 1936 und Toschia Caporiacco 1949 (Arachnida: Araneae: Linyphiidae) // Senckenbergiana Biologica. Bd.58. S.257-260.

Responsible editor K.G. Mikhailov 